\title{
Turbocharging With Air Conditioner Assisted Intercooler
}

\author{
Mohd Muqeem \\ (Mechanical Engineering Department, Teerthanker Mahaveer University, India)
}

\begin{abstract}
The objective of a turbocharger is to improve an engine's volumetric efficiency by increasing the density of the intake gas (usually air, entering the intake manifold of the engine). When the pressure of the engine's intake air is increased, its temperature will also increase. Turbocharger units make use of an intercooler to cool down the intake air. Here, our purpose is to bring the temperature of intake air nearer to the ambient temperature. The intercooling of intake air is greatly increased by installing a specially designed intercooler in which air will run as hot fluid and refrigerant, of the air conditioning system coming from cooling coil fitted in the dashboard, will run as cold fluid. The intake air will be cooled down by the air flowing through the fins of the intercooler and the refrigerant coming from the evaporator. And hence the density of air is increased by increasing the temperature drop across the intercooler.
\end{abstract}

Keywords - Air conditioner, intake manifold, intercooler, supercharger, turbocharger.

\section{Introduction}

Both gasoline and diesel engines that use superchargers and turbochargers face their own unique problems with intake air temperature. Superchargers and turbochargers significantly heat the intake air as they compress it to create boost. The higher boost pressure increases the air density, but the increased temperature of the air can largely offset this density gain. It is desirable to cool the compressed air before it enters the engine. In most cases cooling the compressed air with an intercooler, increases the air density more than any density losses that occur due to the accompanying pressure drop due to cooling or flow restrictions through an intercooler. In other words, inter cooling results in a net density increase for the air entering the cylinder. Intercooling also provides other benefits. For supercharged or turbocharged gasoline engines, reducing the intake air temperature suppresses detonation, just as it does for normally-aspirated gasoline engines. For diesel engines, intercooling increases charge density.

\subsection{General Problems Associated With the Intercooler of Turbocharger}

In the normal turbocharger system, the main problem is that in the countries where summers are very hot, the efficiency of intercooler goes on decreasing as the ambient temperature increases because the intercooler cools the hot air when relatively cold air passes through its fins. But in summers, the air temperature, which passes through the fins of the intercooler to take the heat of the hot air, is already high, so the efficiency of the intercooler gets decreased. Second drawback of this intercooler is that it works properly when the vehicle is running at high speed so that air passes through the fins of the intercooler at suitable speed which is fitted at the front of the vehicle otherwise the intercooler will not be able to reject the heat taken from the hot air. It means intercooler of normal turbo unit is more efficient at high speeds and its efficiency goes on decreasing as the speed of vehicle decreases. When an intercooler is working effectively, the intake air arrives hot and leaves a lot colder. Therefore, there's a temperature drop across the core. A perfectly efficient intercooler would drag the temperature of the compressed air down to ambient. But no intercooler is perfectly efficient, so the temperature drop across the core is always much less than this. For example, when a car first comes on boost, the temp drop across the intercooler might be $40{ }^{\circ} \mathrm{C}$ - the air coming from the turbo or supercharger is at $90{ }^{\circ} \mathrm{C}$ but after the intercooler it is decreased to $50{ }^{\circ} \mathrm{C}$, a $40{ }^{\circ} \mathrm{C}$ drop. However, stay on boost for a longer period and the intercooler will start to heat-soak, its efficiency (and so the temperature drop across the core) getting less and less. With some intercoolers, after being on boost for a while, the temp drop across the core can end up being only about $10{ }^{\circ} \mathrm{C}$.

\section{How a Turbocharger Works}

A turbocharger is a small radial fan pump driven by the energy of the exhaust gases of an engine. A turbocharger consists of a turbine and a compressor on a shared shaft. The turbine section of a turbocharger is a heat engine in itself. It converts the heat energy from the exhaust to power, which then drives the compressor, compressing ambient air and delivering it to the air intake manifold of the engine at higher pressure, resulting in a greater mass of air entering each cylinder. In some instances, compressed air is routed through an intercooler before introduction to the intake manifold. Because a turbocharger is a heat engine, and is converting otherwise wasted exhaust heat to power, it compresses the inlet air to the engine more efficiently than a supercharger. 
A naturally aspirated automobile engine uses only the downward stroke of a piston to create an area of low pressure in order to draw air into the cylinder through the intake valves. Because the pressure in the atmosphere is no more than 1 bar (approximately $14.7 \mathrm{psi}$ ), there ultimately will be a limit to the pressure difference across the intake valves and thus the amount of airflow entering the combustion chamber. This ability to fill the cylinder with air is its volumetric efficiency. Because the turbocharger increases the pressure at the point where air is entering the cylinder, a greater mass of air (oxygen) will be forced in as the inlet manifold pressure increases. The additional oxygen makes it possible to add more fuel, increasing the power and torque output of the engine.

Because the pressure in the cylinder must not go too high to avoid detonation and physical damage, the intake pressure must be controlled by controlling the rotational speed of the turbocharger. The control function is performed by a waste gate, which routes some of the exhaust flow away from the exhaust turbine. This controls shaft speed and regulates air pressure in the intake manifold. The application of a compressor to increase pressure at the point of cylinder air intake is often referred to as forced induction. Centrifugal superchargers compress air in the same fashion as a turbocharger. However, the energy to spin the supercharger is taken from the rotating output energy of the engine's crankshaft as opposed to normally exhausted gas from the engine. Superchargers use output energy from an engine to achieve a net gain, which must be provided from some of the engine's total output. Turbochargers, on the other hand, convert some of the piston engine's exhaust into useful work. This energy would otherwise be wasted out the exhaust. This means that a turbocharger is a more efficient use of the heat energy obtained from the fuel than a supercharger.

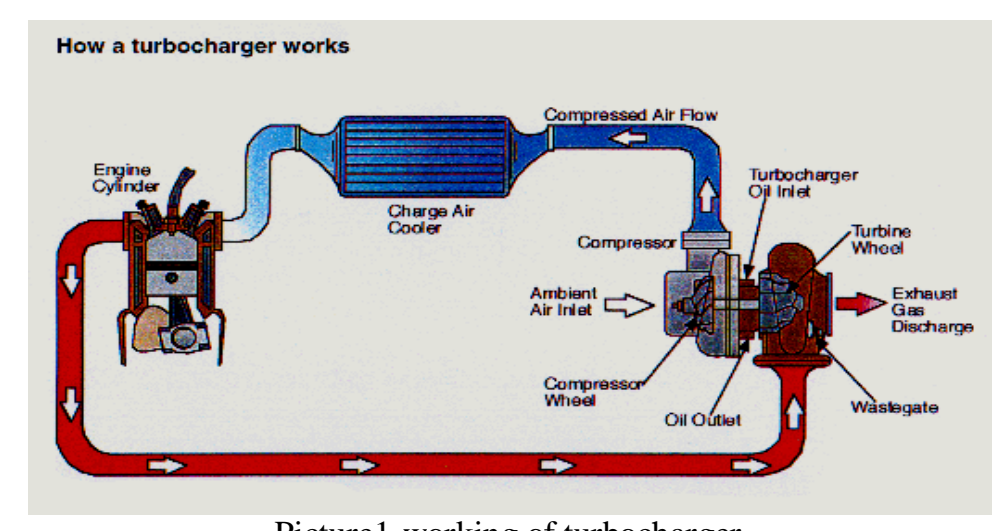

Picture1-working of turbocharger

\subsection{Components of Turbocharger}

The turbocharger has four main components. The turbine (almost always a radial turbine) and impeller/compressor wheels are each contained within their own folded conical housing on opposite sides of the third component, the center housing/hub rotating assembly (CHRA).The housings fitted around the compressor impeller and turbine collect and direct the gas flow through the wheels as they spin. The size and shape can dictate some performance characteristics of the overall turbocharger. Often the same basic turbocharger assembly will be available from the manufacturer with multiple housing choices for the turbine and sometimes the compressor cover as well. This allows the designer of the engine system to tailor the compromises between performance, response, and efficiency to application or preference. Twin-scroll designs have two valve-operated exhaust gas inlets, a smaller sharper angled one for quick response and a larger less angled one for peak performance.

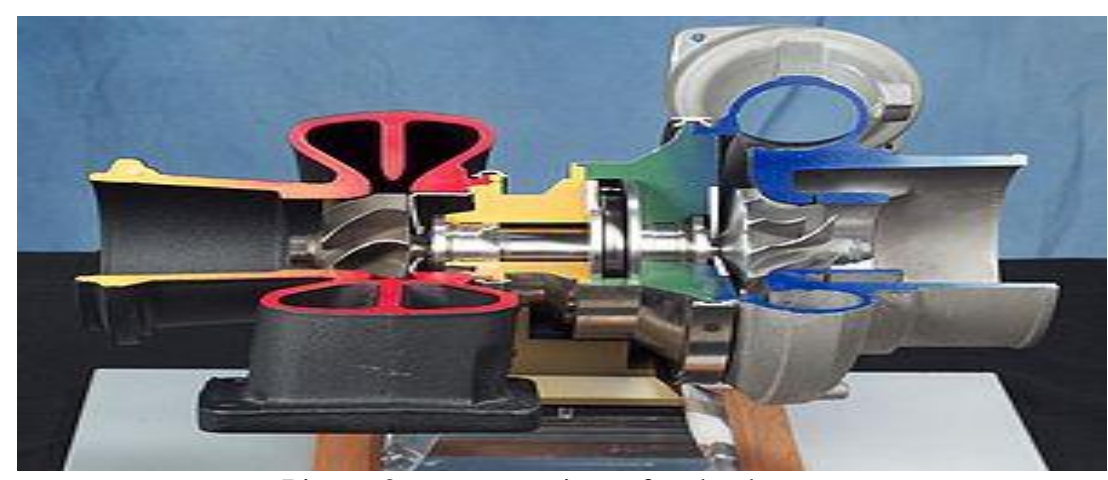

Picture2-cut-away view of turbocharger 


\section{Turbocharging System with Air Conditioner Assisted Intercooler}

In this system the air conditioning system is used to assist the turbocharging system. In summers, when the efficiency of the intercooler is low due to high ambient temperature, the air conditioning system will be used to improve its efficiency because in summers, normally the $\mathrm{AC}$ is always switched on while we drive and on the other hand, we don't need this system in winters because the ambient temperature is sufficiently cool to improve the efficiency of the intercooler. So the design of the intercooler is such that it will work properly with and without the air conditioning system (i.e. in summers and winters both). Besides this it will also increase the charge density to high extent. This will increase the oxygen availability in the cylinder for combustion.

Circulating refrigerant enters the compressor in the thermodynamic state known as a saturated vapor and is compressed to a higher pressure, resulting in a higher temperature as well. The hot, compressed vapor is then in the thermodynamic state known as a superheated vapor and it is at a temperature and pressure at which it can be condensed in the condenser. That hot vapor is routed through a condenser where it is cooled and condensed into a liquid by flowing through a coil or tubes of the condenser. This is where the circulating refrigerant rejects heat from the system and the rejected heat is carried away by the air. The condensed liquid refrigerant, in the thermodynamic state known as a saturated liquid, is next routed through an expansion valve where it undergoes an abrupt reduction in pressure. That pressure reduction results in the adiabatic flash evaporation of a part of the liquid refrigerant. Then this mixture of vapor and liquid refrigerant is passed through the intercooler of the turbocharger as the cold fluid where it is completely evaporated by absorbing the required latent heat. This cools the hot compressed air flowing in the tubes of intercooler coming from the turbocharger compressor.

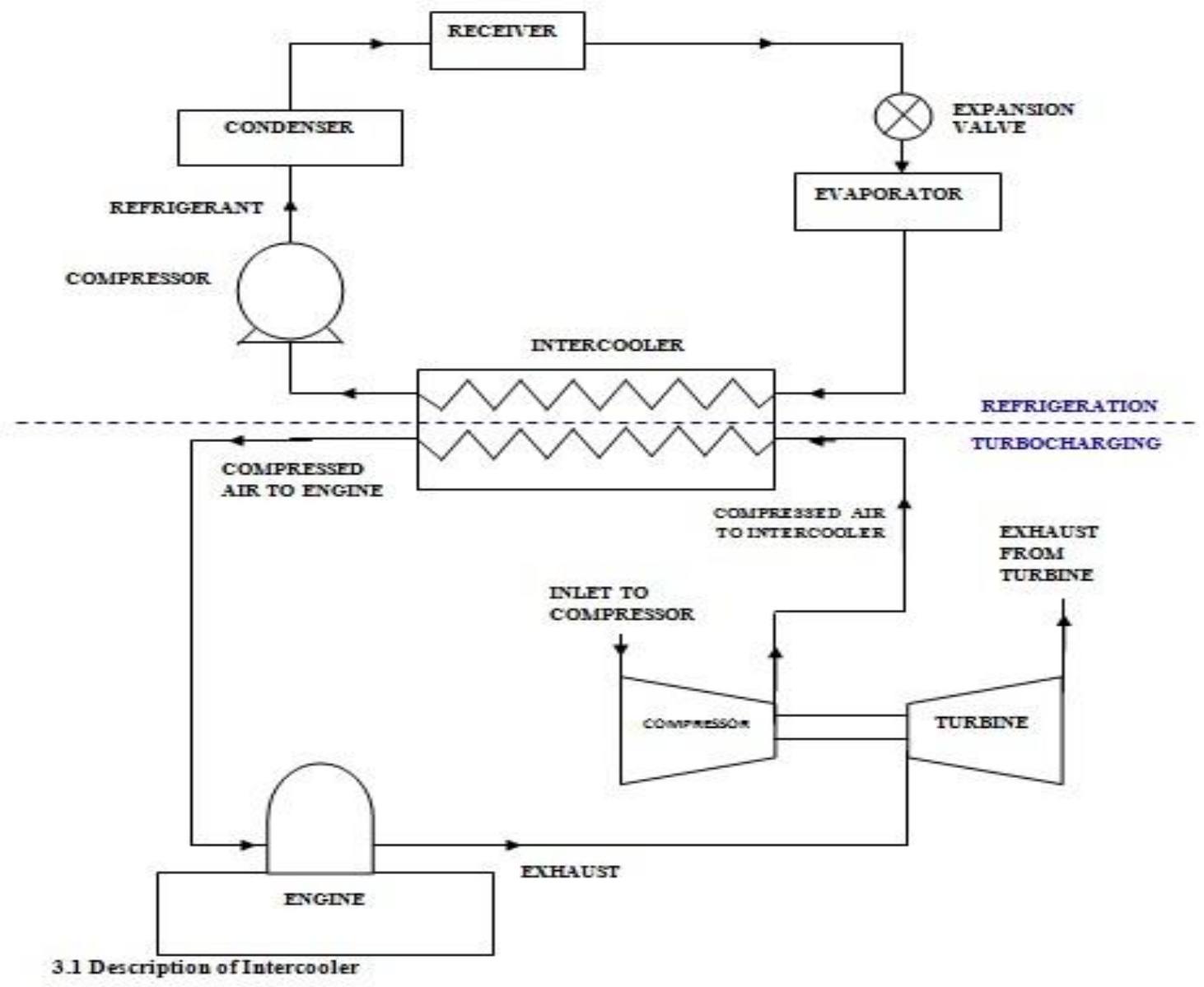

\subsection{Description of Intercooler}

The design of intercooler is such that the air to be cooled is passed through the outer tube and the refrigerant passes through the inner tube of the two concentric tubes arrangement fitted in the arrangement of fins. This type of heat exchanger is suitable for our purpose because when the air conditioning system (AC) is running, the hot air can give its heat to both, the refrigerant and the cold air passing through the fins of the intercooler. When the AC is not running, the hot air from the turbocharger can give its heat to the cold air passing through the fins and will work as the normal intercooler. In winters, the intercooler will work as a normal intercooler and in summers, it will be assisted by the air conditioning system of the vehicle. 


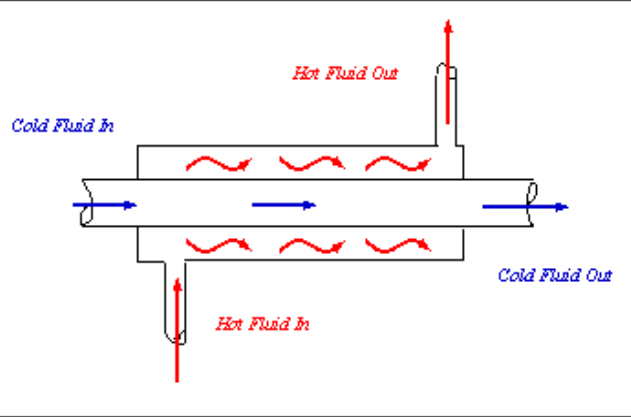

Figure2-concentric tubes arrangement of the intercooler

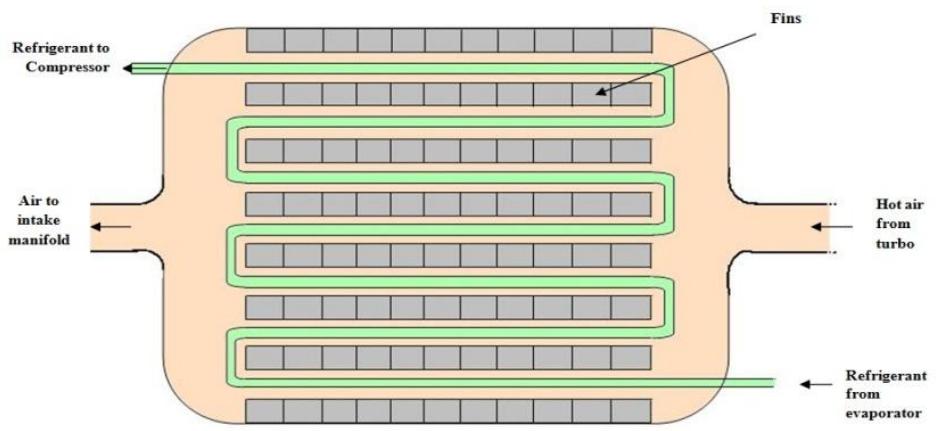

\subsection{Analysis of refrigeration in the intercooler}

When the refrigerant comes to the evaporator after passing through the expansion valve, it absorbs its latent heat of vaporization and gets evaporated. In the evaporator it absorbs about $85-90 \%$ of its latent heat and does not reaches its saturation point. It means, here the refrigerant is in dual phase, about $90 \%$ vapor and remaining in the liquid state as shown in the graph below. Then this refrigerant goes to the intercooler of the turbocharger where it absorbs the remaining latent heat of vaporization from the hot air coming from the compressor of turbocharger and gets evaporated. Now the refrigerant reaches near about its saturation point and then goes to the compressor unit to get compressed. The graph below shows that from point $1-2$, about $90 \%$ of the refrigerant get evaporated and remaining gets evaporated in the intercooler, represented by the line $2-2$ '. The area under the line 1-2 (i.e. area 1-2-b-a-1) is the work done by the compressor per cycle and the area under the line 2-2' (i.e. area 2-2'-c-b-2) is the extra work done by the compressor per cycle because of inter cooling. But this extra work done is negligible as compared to the work done represented by area 1-2-b-a-1. So, we concluded that on passing the refrigerant through the intercooler, there is little extra burden on the compressor of the refrigeration system and can be neglected.

Point 1 to 2- Partial evaporation of the refrigerant in the evaporator.

Point 2 to 2'- Remaining evaporation of the refrigerant in the intercooler of the turbocharger.

Point 2' to 3-Compression of the refrigerant in the compressor unit.

Point 3 to 4 - Condensation of the refrigerant in the condenser.

Point 4 to 1-Expansion of the compressed refrigerant through the expansion valve.

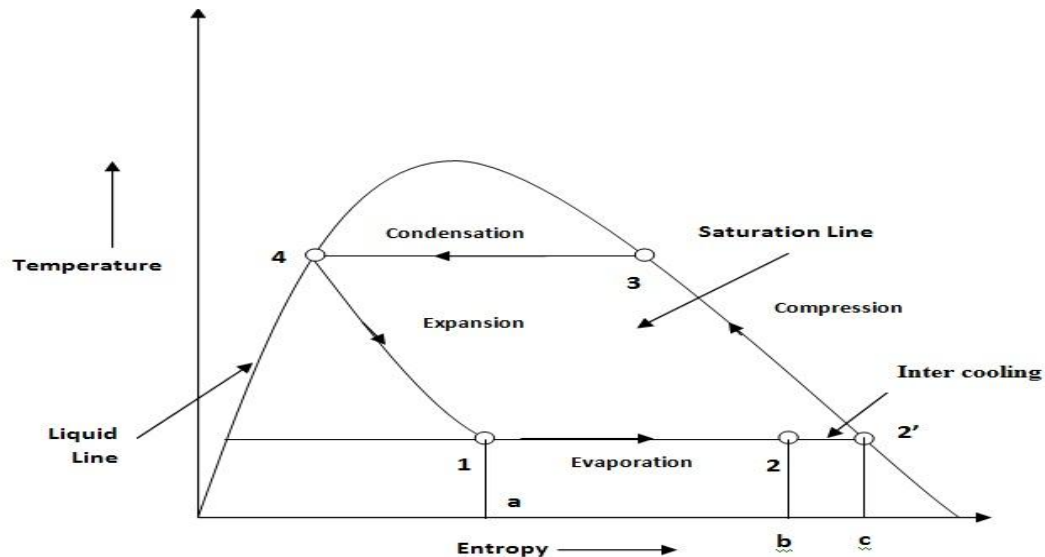

Figure3-temperature entropy diagram of refrigeration cycle 


\subsection{Analysis of the processes within the intercooler.}

In the intercooler there is constant pressure intercooling. Here our main purpose is the measurement of drop in the temperature of the air to be cooled between the inlet and the outlet of the intercooler. Calculation of amount of heat being exchanged between the hot and cold fluid is not required.

Suppose,

$\mathrm{T}_{1}=$ temperature of air entering the intercooler

$\mathrm{T}_{2}=$ temperature of air leaving intercooler when the intercooler is normal

$\mathrm{T}_{3}=$ temperature of air leaving intercooler when the intercooler is refrigerated

$\mathrm{v}_{1}=$ specific volume of air entering the intercooler

$\mathrm{v}_{2}=$ specific volume of air leaving the intercooler when the intercooler is normal

$\mathrm{v}_{3}=$ specific volume of air leaving the intercooler when the intercooler is refrigerated

$\mathrm{P}_{1}=$ Pressure of air entering the intercooler

$\mathrm{P}_{2}=$ Pressure of air leaving the intercooler when the intercooler is normal

$\mathrm{P}_{3}=$ Pressure of air leaving the intercooler when the intercooler is refrigerated

We know that the general gas equation is as follows:

$$
\begin{aligned}
& \frac{\mathrm{P}_{1} \mathrm{v}_{1}}{\mathrm{~T}_{1}}=\frac{\mathrm{P}_{2} \mathrm{v}_{2}}{\mathrm{~T}_{2}} \\
& \text { But, } \quad \mathrm{P}_{1}=\mathrm{P}_{2}=P_{3} \quad \text { (Constant pressure intercooling) } \\
& \text { So, } \quad \frac{v_{1}}{T_{1}}=\frac{v_{2}}{T_{2}} \\
& \text { Therefore, } \quad \frac{T_{1}}{T_{2}}=\frac{v_{1}}{v_{2}} \\
& \text { And } \quad v_{2}=\frac{T_{2}}{T_{1}} \cdot v_{1}----(1) \quad \text { (for normal intercooler) } \\
& \text { Similarly } \quad \mathrm{v}_{3}=\frac{\mathrm{T}_{3}}{\mathrm{~T}_{1}} \cdot \mathrm{v}_{1}-\cdots-- \text { (2) (for refrigerated intercooler) }
\end{aligned}
$$

If $\mathrm{v}_{1}, \mathrm{v}_{2}$ and $\mathrm{v}_{3}$ are the specific volumes of air in $\mathrm{m}^{3} / \mathrm{kg}$ entering and leaving the intercooler then the density of air at inlet and the outlet will be $\frac{1}{v_{1}}, \frac{1}{v_{2}}$ and $\frac{1}{v_{3}}$ (reciprocals of the specific volumes) in $\mathrm{kg} / \mathrm{m}^{3}$.

If the air directly enters the engine cylinder (without intercooling) having swept volume $\mathrm{v}^{3}$, then the mass of oxygen entering the cylinder will be

$$
\begin{aligned}
& =\text { swept volume } \mathrm{x} \text { density } \mathrm{x} \text { percentage of oxygen in air } \\
& =\mathrm{v} \cdot \frac{1}{\mathrm{v}_{1}} \times 0.21 \\
& =\frac{0.21 v}{v_{1}}
\end{aligned}
$$

Case 1- When the air enters the engine cylinder after normal intercooling.

Then the mass of oxygen entering the cylinder will be

$$
\begin{aligned}
& =\text { swept volume } \mathrm{x} \text { density } \mathrm{x} \text { percentage of oxygen in air } \\
& =\mathrm{v} \cdot \frac{1}{\mathrm{v}_{2}} \times 0.21 \\
& =\frac{0.21 v}{v_{2}}
\end{aligned}
$$

Then increase in mass of oxygen entering the engine cylinder will be as follows,

$$
\begin{aligned}
& =\frac{0.21 v}{v_{2}}-\frac{0.21 v}{v_{1}} \\
& =\frac{0.21 v\left(v_{1}-v_{2}\right)}{v_{1} v_{2}}
\end{aligned}
$$

Percentage increase in the mass of oxygen entering the engine cylinder,

$$
\begin{aligned}
& =\frac{\frac{0.21 v\left(v_{1}-v_{2}\right)}{v_{1} v_{2}}}{\frac{0.21 v}{v_{1}}} \times 100 \\
& =\frac{100\left(v_{1}-v_{2}\right)}{v_{2}} \\
& \left.=\frac{100\left(v_{1}-\frac{\mathrm{T}_{2}}{\mathrm{~T}_{1}} \cdot \mathrm{v}_{1}\right)}{\frac{\mathrm{T}_{2}}{\mathrm{~T}_{1}} \cdot \mathrm{v}_{1}} \quad \text { (From eq. } 1 \quad \mathrm{v}_{2}=\frac{\mathrm{T}_{2}}{\mathrm{~T}_{1}} \cdot \mathrm{v}_{1}\right) \\
& =\frac{100\left(1-\frac{\mathrm{T}_{2}}{\mathrm{~T}_{1}}\right)}{\frac{\mathrm{T}_{2}}{\mathrm{~T}_{1}}} \quad \text {---------- (3) }
\end{aligned}
$$

Case 2- When the air enters the engine cylinder after refrigerated intercooling,

Similarly percentage increase in the mass of oxygen entering the engine cylinder, 


$$
=\frac{100\left(1-\frac{\mathrm{T}_{3}}{\mathrm{~T}_{1}}\right)}{\frac{\mathrm{T}_{3}}{\mathrm{~T}_{1}}}
$$

\section{Experimental setup and procedure}

A four stroke four cylinder turbocharged diesel engine of an automobile vehicle was used for the performance test of intercooler. Various readings of temperatures were recorded at different RPMs of the engine across the intercooler inlet and outlet. To measure the temperature, two sensors are placed at the inlet and outlet. The two sensors are called thermistors - they are components that change in resistance with temperature. These two sensors are connected to an electronic temperature measuring device which records the temperature of air at the inlet and the outlet at different RPMs of the engine.

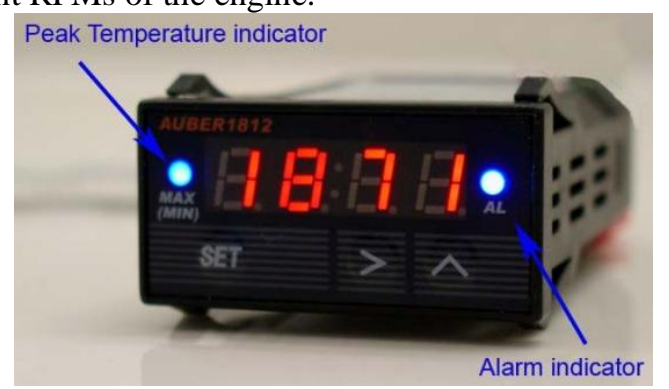

Picture3- temperature measuring device

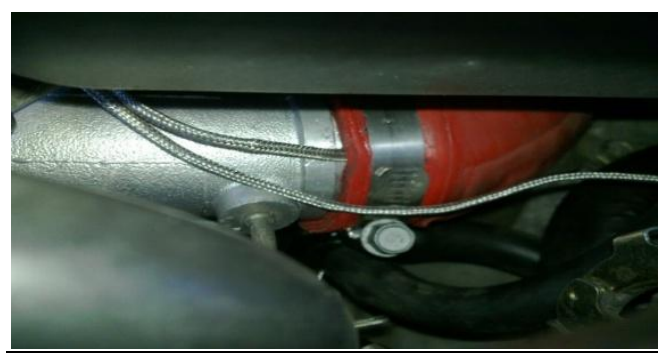

Picture4- thermistor fitted at the inlet of intercooler

\subsection{Results and Discussion}

Readings were taken by gradually increasing the RPMs of the engine and the time interval between each reading is about 5 minutes, so that the engine gets heated up and stay on boost for a longer period and the intercooler will have started to soak heat and all possible chances of decreasing its efficiency have reached.

Table 1 - Observation Table for Normal Air Cooled Intercooler

\begin{tabular}{|c|c|c|c|c|c|}
\hline $\begin{array}{l}\text { Readi } \\
\text { ng } S . \\
\text { No. }\end{array}$ & $\begin{array}{l}\text { RPM of } \\
\text { the engine }\end{array}$ & $\begin{array}{l}\text { Ambient } \\
\text { Temperatu } \\
\text { re } \\
{ }^{\circ} \mathrm{C}\end{array}$ & $\begin{array}{l}\text { Temperature of air } \\
\text { at the inlet of the } \\
\text { intercooler } \\
\left(\mathrm{T}_{1}\right){ }^{\circ} \mathrm{C}\end{array}$ & $\begin{array}{l}\text { Temperature of air at } \\
\text { the outlet of the } \\
\text { intercooler } \\
\left(\mathrm{T}_{2}\right){ }^{\circ} \mathrm{C}\end{array}$ & $\begin{array}{l}\text { Temperature } \\
\text { drop across the } \\
\text { intercooler, }{ }^{\circ} \mathrm{C}\end{array}$ \\
\hline 1. & 2800 & \multirow{6}{*}{20} & 89 & 45 & 44 \\
\hline 2. & 3200 & & 93 & 55 & 38 \\
\hline 3. & 3600 & & 99 & 68 & 31 \\
\hline 4. & 4000 & & 105 & 77 & 28 \\
\hline 5. & 4400 & & 111 & 86 & 25 \\
\hline 6. & 4800 & & 118 & 99 & 19 \\
\hline
\end{tabular}

Observations for the specially designed refrigerated and air cooled intercooler were taken in the same manner next day after installing the new intercooler.

Table 2 - Observation Table For Specially Designed Refrigerated and Air Cooled Intercooler

\begin{tabular}{|c|c|c|c|c|c|}
\hline $\begin{array}{l}\text { Readin } \\
\text { g S. } \\
\text { No. }\end{array}$ & $\begin{array}{l}\text { RPM of } \\
\text { the engine }\end{array}$ & $\begin{array}{l}\text { Ambient } \\
\text { Temperatur } \\
\mathrm{e} \\
{ }^{\circ} \mathrm{C}\end{array}$ & $\begin{array}{l}\text { Temperature of air at } \\
\text { the inlet of the } \\
\text { intercooler } \\
\left(\mathrm{T}_{1}\right)^{\circ} \mathrm{C}\end{array}$ & $\begin{array}{l}\text { Temperature of air at the } \\
\text { outlet of the intercooler } \\
\left(\mathrm{T}_{3}\right)^{\circ} \mathrm{C}\end{array}$ & $\begin{array}{l}\text { Temperature drop } \\
\text { across the } \\
\text { intercooler, }{ }^{\circ} \mathrm{C}\end{array}$ \\
\hline 1. & 2800 & \multirow{3}{*}{19} & 87 & 22 & 65 \\
\hline 2. & 3200 & & 92 & 28 & 64 \\
\hline 3. & 3600 & & 96 & 34 & 62 \\
\hline
\end{tabular}


Turbocharging With Air Conditioner Assisted Intercooler

\begin{tabular}{|l|l|l|l|l|l|}
\hline \hline 4. & 4000 & & 38 & 63 \\
\cline { 1 - 1 } 5. & 4400 & 101 & 51 & 59 \\
\cline { 5 - 6 } & 4800 & 110 & 62 & 57 \\
\cline { 5 - 6 } & & 119 & 62 & \\
\hline
\end{tabular}

4.2 Calculations for the percentage increase in the mass of oxygen entering into intake manifold of the engine.

Case 1- When the air enters into intake manifold of the engine through normal air cooled intercooler.

Taking average of all readings of temperature of air at the inlet and outlet of the intercooler, we have

$\mathrm{T}_{1}=102.5^{\circ} \mathrm{C}$ and

$\mathrm{T}_{2}=71.67^{\circ} \mathrm{C}$

Now from equation 3 , we have

Percentage increase in the mass of oxygen $=\frac{100\left(1-\frac{T_{2}}{T_{1}}\right)}{\frac{T_{2}}{T_{1}}}$

$$
\begin{aligned}
& =\frac{100\left(1-\frac{71.67}{102.5}\right)}{\frac{71.67}{102.5}} \\
& =43.06 \%
\end{aligned}
$$

Case 2- When the air enters into intake manifold of the engine through specially designed refrigerated and air cooled intercooler.

Taking average of all readings of temperature of air at the inlet and outlet of the intercooler, we have

$\mathrm{T}_{1}=100.83{ }^{\circ} \mathrm{C}$ and

$\mathrm{T}_{2}=39.16^{\circ} \mathrm{C}$

(Note: The ambient temperature and the temperature of air coming out of turbo compressor at different RPMs are approximately same for the both the cases, means values of $T_{1}$ for both the cases are approximately same. So either value $\mathrm{T}_{1}=102.5{ }^{\circ} \mathrm{C}$ or $\mathrm{T}_{1}=100.83{ }^{\circ} \mathrm{C}$ may be chosen. Here the value of $\mathrm{T}_{1}$ is chosen as for case 1 for for the easy comparison of two cases. )

$\mathrm{T}_{1}=102.5^{\circ} \mathrm{C}$ and

$\mathrm{T}_{2}=39.16^{\circ} \mathrm{C}$

Now from equation 4 , we have

$$
\begin{aligned}
\text { Percentage increase in the mass of oxygen } & =\frac{100\left(1-\frac{T_{3}}{T_{1}}\right)}{\frac{T_{3}}{T_{1}}} \\
& =\frac{100\left(1-\frac{39.16}{10.5}\right)}{\frac{39.16}{102.5}} \\
& =161.78 \%
\end{aligned}
$$

\section{Conclusion}

From the above collected data and calculations, it is being concluded that when normal air cooled intercooler is used to cool down the hot air before entering into the engine cylinder, the mass of oxygen being fed to the engine becomes 1.43 times but when refrigerated intercooler is used, it becomes 2.618 times. Increasing the oxygen content with the air leads to faster burn rates and the ability to control exhaust emissions. Added oxygen in the combustion air offers more potential for burning diesel.

\section{Acknowledgements}

The experiment was carried out in Akanksha Automobiles Pvt. Ltd., Moradabad, Uttar Pradesh, India, an authorized Maruti Suzuki service centre, with the co-operation of senior technician of diesel section Mr.Farjand Ali.

\section{References}

[1] Flynn, P.F.:"Turbocharging Four-Cycle Diesel Engines" SAE paper 790314, SAE trans., vol. 88, 1979.

[2] Watson, N., and Janota, M.S.: Turbocharging the Internal Combustion Engine, Wiley-Interscience Publications, John Wiley, New York, 1982.

[3] Gyssler, G.: "Problems Associated with Turbocharging Large Two-Stroke Diesel Engines" Proc. CIMAC, paper B.16, 1965.

[4] Bhinder, F.S.:"Supercharging Compressors-Problems and Potentials of the Various Alternatives," SAE paper 840243, 1984.

[5] John B. Heywood, "Internal Combustion Engine Fundamentals", McGraw-Hill series in mechanical engineering.

[6] Magdi S. Mahmoud,"Improved Controller Design for Turbocharged Diesel Engine", Proceedings of the World Congress on Engineering 2012 Vol III WCE 2012, July 4 - 6, 2012, London, U.K.

[7] Cooper, A.R.; Morrow, D.J.; Chambers, K.D.R.;"A turbocharged diesel generator set model," Proc. of the 44th Inte. Universities Power Engineering Conference (UPEC), 1-4 Sept. 2009, pp. 1-5. 